Jurnal Keuangan dan Perbankan, Vol.20, No.2 Mei 2016, hlm. 322-333

Terakreditasi SK. No. 040/P/2014

http://jurkubank.wordpress.com

\title{
IMPLEMENTASI MODEL PENILAIAN KINERJA BERBASIS KNOWLEDGE MANAGEMENT SCORE CARD GUNA MENINGKATKAN KUALITAS DAN KEMANDIRIAN LEMBAGA KEUANGAN MIKRO “BKAD” DI JAWA TIMUR
}

\author{
Yuntawati Fristin \\ Fakultas IImu Sosial dan IImu Politik, Universitas Merdeka Malang \\ Fajar Supanto \\ Umu Khouroh \\ Fakultas Ekonomi dan Bisnis, Universitas Merdeka Malang
}

\begin{abstract}
Knowledge management as the process by which organizations accumulate intellectual capital and use it to gain competitive advantage. When organizations make a huge investment to intellectual assets, the organiza-tion must be able to measure the impact of knowledge management (KM) to the organization (tangible out-comes) and is confident that by the organization in order to collect the knowledge assets in line with the vision of the organization's mission. The objective of the research is to develop and test-development model of performancebased Knowledge Management (KM) Scorecard well as formulate a program for the development of BKAD based on intellectual capital owned.To achieve the objective, the research is carried out with the approach of participant observation. The result indicates that the assessment of KM scorecard in general provides adequately fine results when they are seen from four perspectives, those are intellectual, social, structural and humanity. The activities of human resource development (PSDM), natural resource develop-ment (PSDA), and economic resource development (PSDE) have resulted in economic increase, knowledge and skill increase, and have opened job opportunities and foster entrepreneurship opportunity. Seen from business development of real sector, BKAD has succeed to develop business of real sector based on areal resources which is in accordance with its regional potency.
\end{abstract}

Keywords: knowledge-management-scorecard, human resource development, natural resource development, economic resource development

\section{PENDAHULUAN}

Knowledge yang terdapat pada SDM maupun organisasi, merupakan salah satu bentuk intan- gible asset yang tidak kalah berharganya dibandingkan dengan intangible asset yang lain bahkan merupakan elemen intangible asset yang paling berharga karena faktor manusia sebenarnya sebagai faktor

Korespondensi dengan Penulis:

Fajar Supanto: +6281235188181

Email: myfajar@gmail.com 
penentu (driver) intangible asset yang lain. Hal ini-lah yang menyebabkan manusia menjadi salah satu faktor sumber daya yang sangat signifikan peranannya dalam organisasi, terutama bagi organisasi yang sangat bergantung pada SDM. Perpindahan SDM dari sebuah organisasi menjadi permasalahan tersendiri bagi organisasi tersebut, karena perpindahan SDM tersebut sebenarnya bukan hanya perpindahan secara fisik SDM, namun juga perpindahan skill dan knowledge yang semula menjadi bagian organisasi asalnya dimana SDM tersebut berada, terlebih jika SDM tersebut merupakan orang kunci dalam organisasi tersebut.

Knowledge yang dihubungkan dengan suatu kapasitas intelektual dapat mendorong kreativitas dalam meningkatkan produktivitas, mendorong lahirnya dunia usaha yang kompetitif, serta caracara produksi yang lebih efisien dan mutakhir (McElroy, 2003). Oleh karena itu, Modal intelektual kini dirujuk sebagai faktor penyebab sukses yang penting dan karenanya akan semakin menjadi suatu tumpuan perhatian dalam kajian strategi organisasi dan strategi pembangunan. Penyim-pulan ini dibasiskan pada temuan tentang kinerja organisasi, khususnya organisasi-organisasi yang padat pengetahuan (knowledge-intensive organiza-tions) (Bounfour and Edvinsson 2005; Lonnqvist dan Mettanen).

Pada tataran mikro, agak sulit untuk tidak mengaitkan perkembangan ini di dalam konteks persaingan dan pencarian basis keunggulan kompetitif. Nilai ekonomis dan keunggulan kompetitif sebuah organisasi ekonomi terletak pada kepemi-likan dan pemanfaatan secara efektif sumber daya organisasi yang mampu menambah nilai (valuable), bersifat jarang dimiliki (scarce), sulit untuk ditiru (imperfectly immitable), dan tidak tergantikan oleh sumber daya lain (non-substitutable) (Lewin and Phelan 1999; Wright, McMahan, dan McWilliams 1992). Oleh karena itu, strategi bersaing harus dile-takkan pada upaya mencari, mendapatkan, mengem-bangkan, dan mempertahankan dua sumber daya strategis yaitu manusiadan organisasi. Dalam istilah yang berbeda, dapat disandingkan dengan kon-sep modal intelektual.

Survei yang dilakukan EPRI (Strategic Hu-man Performance Program) menunjukkan bahwa 92\% organisasi yakin bahwa kehilangan SDM ahli akan berdampak serius bahkan hingga jangka panjang dan menariknya dari $92 \%$ tersebut, hanya $30 \%$ yang melakukan langkah transfer ilmu dari staf ahli kepada staf yunior. Hal inilah yang menyebabkan manusia menjadi salah satu faktor sumber daya yang sangat signifikan peranannya dalam organisasi, terutama bagi organisasi yang sangat bergantung pada SDM. Oleh karena itu knowledge harus dikelola dengan baik oleh organisasi, dimana konsep ini disebut sebagai KM (knowledge management).

Konsep KM diterapkan dengan tujuan untuk meningkatkan dan memperbaiki pengoperasian perusahaan dalam rangka meraih keuntungan kompetitif dan meningkatkan laba.Knowledge management berfungsi meningkatkan kemampuan organisasi untuk belajar dari lingkungannya dan menggabungkan pengetahuan dalam organisasi untuk menciptakan, mengumpulkan, memelihara dan mendiseminasikan pengetahuan. Dalam lingkup yang lebih luas knowledge management dalam organisasi akan menjadi dasar bagi timbulnya masyarakat berbasis pengetahuan (knowledge-based society).

Program Pengembangan Sumberdaya Lokal Berbasis Kawasan (P2SLBK) Provinsi Jawa Timur merupakan salah program pengentasan kemiskinan yang bergerak dalam bidangjasa pelayanan ke-uangan mikro yang bernama Badan Kerjasama Antar Desa (BKAD)dengan tujuan mewujudkan kemandirian ekonomi masyarakat melalui pengem-bangan potensi wilayah yang berorientasi pada percepatan pertumbuhan ekonomi dan penciptaan lapangan kerja.

Sebagai lembaga yang lebih banyak melakukan fungsi sosial tanpa mengabaikan fungsi ekonominya, seringkali BKAD dihadapkan pada turn 


\section{Jurnal Keuangan dan Perbankan | PERBANKAN}

Vol. 20, No.2, Mei 2016: 322- 333

over SDM yang tinggi sehingga keluarnya SDM yang berkualitas menghambat keberlangsungan lembaga. Oleh karena itu, BKAD sudah selayaknya melakukan perubahan pada pengelolaan institusinya terutama dalam memaksimalkan asset intelektual. Oleh karena itu elemen-elemen dalam pengelolaan knowledge seperti penciptaan knowledge (knowledge creation), pengalihan knowledge (knowledge transfer) dan penyebaran knowledge (knowledge dissemination) akan menjadi tolok ukur berkembang tidaknya organisasi.

Penelitian ini dilakukan dengan tujuan mengem-bangkandan uji coba model pengembangan kinerja yang berbasis Knowledge Management Scorecard. Model ini dikembangkan dengan mengadaptasi konsep Balance Scorecard yang banyak diadopsi menjadi suatu model yang dapat mengukur aset knowledge dan modal intelektual suatu organisasi (Maholtra, 2003). Dengan menggunakan model ini, visi, misi bahkan strategi organisasi dapat diarah-kan pada peningkatan kompetensi inti sehingga menghasilkan luaran inovatif. Melalui model ini diharapkan pengembangan kinerja yang berfokus pada capital intellectual BKAD dan lembaga atau organisasi lainnya dapat diajukan sebagai acuan untuk pengembangan organisasi terutama pada lembaga yang masa depannya sangat bergantung pada SDM yang ada.

Pengelolaan knowledge sangat berhubungan dengan strategi yang kompetitif yang memberi keuntungan besar bagi daerah pasarnya (Nonaka, 1991). Lebih lanjut Nonaka menjelaskan bahwa pengelolaan knowledgeadalah proses mendapatkan intelegensia dan kepakaran kolektif serta meng-gunakannya untuk mengembangkan inovasi me-lalui pembelajaran organisasional yang terus me-nerus.

Pisano (1994) mengungkapkan tiga hal dalam proses konversi tersebut yaitu proses pengalihan knowledge (tranfer knowledge); proses penciptaan knowledge (create knowledge) dan proses saling ber- bagi (sharing knowledge). Ketiga proses diatas didukung oleh suatu pengelolaan yang didasarkan pada isu yang terkait yaitu 1) teknologi informasi. Dalam hal ini dukungan TI yang menonjol adalah pada teknologi komunikasi; teknologi kolaborasi; pengelolaan dokumen; teknologi adaptasi; lingkungan e-learning; infrastruktur seperti teknologi networking (Marwick, 2001); 2) budaya orga-nisasi dan team work; dan 3) pengukuran intelektual dan asset yang berbasis pengetahuan.

Konsep BSC pada perkembangannnya banyak diadopsi menjadi suatu model yang dapat mengukur aset knowledge dan modal intelektual suatu organisasi (Maholtra, 2003). Dengan menggunakan model ini, visi, misi bahkan strategi organisasi dapat diarahkan pada peningkatan kompetensi inti sehingga menghasilkan luaran inovatif. Fairchild (2002) bahkan mengembangkan konsep BSC dengan mengimplementasi perspektif pada BSC dengan strategi pengelolaan knowledge.

Dengan dasar pertimbangan di atas Fairchild (2002) mengembangkan 4 (empat) perspekti pengelolaan knowledge sebagai kekayaan yang dilandasi pada kompetensi inti, keahlian yang dimiliki dan kebutuhan knowledge. keempat perspektif tersebut adalah sebagai berikut: 1) Humanitas, mengacu pada kapabilitas individual, keahlian, knowledge dan pengalaman pekerja; 2) Structural, mengacu pada asset yang dimiliki, knowledge organisasi, proses pengalihan dari knowledge individu menjadi knowledge organisasi dan teknologi sebagai pendukung mempercepat proses pengalihan knowledge; 3) Social, mengacu pada interaksi (networking); 4) Intelektual, termasuk informasi, invensi, inovasi yang dapat menambah nilai organisasi dan membangun asset yang mele-bihi asset yang terlihat seperti tanah, tenaga kerja atau pendanaan.

\section{METODE}

Rancangan penelitian yang digunakan dengan menggunakan penelitian deskriptif setelah 
sebelumnya data dan informasi yang ada diolah berdasarkan perspektif Knowledge Management Scorecard (KM Scorecard). KM Scorecard merupakan modifikasi dari konsep Balance Scorecard (BSC) sehingga tahapan-tahapan penelitian mengikuti kaidah BSC. Pengkajian yang dilakukan dalam pengelolaan knowledge dilihat dari 4 (empat) perspektif yaitu intelektual, social, structural dan humanitas. Unit analisis adalah pengurus BKAD. Objek utama yang dijadikan dasar pengetahuan untuk merumuskan bagaimana model pengembangan kinerja dan rumusan strategi pengembangan BKAD adalah dengan mempelajari modal intelektual yang mereka miliki serta bagaimana para pengurus BKAD mengelola knowledge serta mengidentifikasi faktor-faktor yang mempengaruhi pengelolaan knowledge.

Lokasi penelitian meliputi 5 Kabupaten di Provinsi Jawa Timur yaitu pada tabel 1.

Kerangka analitik dilakukan dengan mengadopsi konsep yang dikembangkan oleh Fairchild (2002) yaitu KM Scorecard dengan variabel penelitian sebagai berikut pada tabel 2 .

Teknik pengumpulan data dilakukan dengan: 1) Observasi; 2) Penyebaran kuesioner; 3) Wawancara mendalam; 4) FGD dan; 5) Studi pustaka.

Data tersebut kemudian dianalisis lebih lanjut untuk menyusun sasaran prioritas BKAD serta alternatif strategi. Langkah-langkah dalam analisis data:

1. Mengidentifikasi secara deskriptif data yang dihasilkan dari observasi, wawancara, kuesioner dan FGD.

2. Menganalisis pengelolaan knowledge BKAD dengan menggunakan perspektif KM Scorecard.

3. Mengembangkan dan uji coba model KM Scorecard serta merumuskan strategi yang mengacu pada pencapaian sasaran strategi dan ukuran hasil.

\section{HASIL DAN PEMBAHASAN}

Program Pengembangan Sumberdaya Lokal Berbasis Kawasan (P2SLBK) merupakan salah satu program pengentasan kemiskinan dan penanganan pengangguran yang ditekankan pada sektor riil berbasis potensi aktual kawasan. Tujuan program adalah mewujudkan kemandirian ekonomi masyarakat melalui pengembangan potensi wilayah yang berorientasi pada percepatan pertumbuhan ekonomi dan penciptaan lapangan kerja, yang secara langsung berdampak pada penurunan angka kemiskinan. Sasaran Program adalah kegiatan ekonomi produktif masyarakat yang berpotensi untuk dikembangkan serta mempunyai dukungan potensi sumberdaya alam, potensi SDM, serta po-tensi ekonomi lainnya termasuk adanya jejaring usaha yang yang dapat diperkuat guna mem-percepat pertumbuhan ekonomi masyarakat.

\section{Produk spesifik kawasan}

Produk spesifik kawasan pada lokasi kajian adalah: 1) Kabupaten Jombang pada ketiga desa lokasi program yaitu Desa Randuwatang, Sumbernongko dan Bedahlawak memiliki potensi yang sangat besar dalam bidang pertanian ketela Pohon; 2) Kabupaten Pacitan memiliki potensi sumberdaya perkebunan kelapa, dengan luas total lahan perkebunan kelapa di 3 desa $\pm 71,2$ ha; 3) Kabupaten Probolinggo memiliki potensi sumberdaya yang sama yaitu pertanian dimana luas lahan pertanian dari ketiga desa 481,045 ha, berkisar $62 \%$ dari to-tal luas 3 desa serta potensi wisata yang berbasis budaya; 4) Kabupaten Ponorogo memiliki potensi yang hampir sama yaitu tanaman janggelan dan produk makanan yang terbuat dari janggelan yang mampu menembus pangsa pasar luar negeri; 5) Kabupaten Tulungagung yang pada umumnya didominasi oleh struktur batuan yang beraneka ragam membuat daerah ini kaya akan potensi bahan galian golongan $\mathrm{C}$ yaitu batu marmer dan onix, selain itu juga perikanan darat. 
Tabel 1. Lokasi Penelitian

\begin{tabular}{|c|c|c|l|}
\hline \multirow{2}{*}{ NO } & \multirow{2}{*}{ KAB/KOTA } & KECAMATAN & \multicolumn{1}{c|}{ DESA } \\
\hline \multirow{3}{*}{1} & \multirow{3}{*}{ Jombang } & Kudu & Randuwatang \\
\cline { 3 - 4 } & & Ngusikan & Sumbernongko \\
\cline { 3 - 4 } 2 & \multirow{3}{*}{ Tulungagung } & Tembelang & Bedahlawak \\
\cline { 3 - 4 } & & Boyolangu & Wajaklor \\
\cline { 3 - 4 } & & Sumbergempol & Wonorejo \\
\hline \multirow{3}{*}{3} & \multirow{3}{*}{ Pacitan } & Gondang & Gondosuli \\
\hline \multirow{3}{*}{4} & \multirow{3}{*}{ Probolinggo } & Tebonagung & Ketro \\
\cline { 3 - 4 } & & Ngadirojo & Wonoanti \\
\cline { 3 - 4 } & & Gading & Sidomulyo \\
\hline \multirow{2}{*}{5} & \multirow{3}{*}{ Ponorogo } & Pajarakan & Gadingwetan \\
\cline { 3 - 4 } & & Besuk & Karanggeger \\
\cline { 3 - 4 } & & Bungkal & Alaskandang \\
\cline { 3 - 4 } & & Ngrayun & Cepoko \\
\hline
\end{tabular}

Tabel 2. Variabel Penelitian

\begin{tabular}{|l|l|l|}
\hline Perspektif & \multicolumn{1}{|c|}{ Strategi } & \multicolumn{1}{|c|}{ Variabel } \\
\hline Intelektual & Strategi untuk menghasilkan modal intelektual & $\begin{array}{l}\text { Informasi } \\
\text { Invensi } \\
\text { Inovasi }\end{array}$ \\
\hline Sosial & $\begin{array}{l}\text { Strategi membina hubungan baik,membangun } \\
\text { reputasi, memperoleh kepercayaan dalam } \\
\text { bekerja sama }\end{array}$ & $\begin{array}{l}\text { Interaksi; } \\
\text { reputasi; } \\
\text { diseminasi; } \\
\text { kerjasama }\end{array}$ \\
\hline Struktural & $\begin{array}{l}\text { Strategi menciptakan proses, budaya dan iklim } \\
\text { kerja yang baik }\end{array}$ & $\begin{array}{l}\text { Infrastruktur } \\
\text { Knowledge organisasi } \\
\text { Pengalihan Knowledge individu ke } \\
\text { dalam knowledge organisasi, }\end{array}$ \\
& $\begin{array}{l}\text { Teknologi untuk Pengalihan } \\
\text { Knowledge } \\
\text { Kebijakan, peraturan, target, tujuan, } \\
\text { budaya, atmosfer (diskusi) }\end{array}$ \\
\hline Humanitas & $\begin{array}{l}\text { Strategi membina dan mengembangkan } \\
\text { knowledge worker dalam intelektual, } \\
\text { kepakaran dan komitmen menghasilkan } \\
\text { knowledge }\end{array}$ & $\begin{array}{l}\text { Kapabilitas Individu, } \\
\text { keahlian, } \\
\text { Knowledge } \\
\text { pengalaman, sikap dan komitmen }\end{array}$ \\
\hline
\end{tabular}




\section{Pengelolaan BKAD dan UPKu}

Pelaksanaan kegiatan P2SLBK dilaksanakan oleh kelembagaan yang berbasis masyarakat yang dibentuk melalui Musyawarah Desa. Kelembagaan tersebut dikenal dengan nama Badan Kerjasama Antar Desa (BKAD) dan Unit Pengelola Keuangan (UPKu) yang berada di masing-masing desa.

\section{Hasil Penelitian yang dicapai dengan menggunakan Analisis Kondisi BKAD Berdasarkan Perspektif Knowledge Management (KM) Scorecard}

\section{Perspektif Intelektual}

Dalam perspektif intelektual yang menjadi fokus perhatian adalah bagaimana menghasilkan modal intelektual melalui upaya meningkatkan kemampuan untuk memperoleh pengetahuan dan keahlian, serta menghasilkan invensi dan inovasi.

Kegiatan untuk memperoleh dan meningkatkan pengetahuan dan keahlian yang menambah nilai organisasi dilakukan melalui program Pengembangan Sumber Daya Manusia (PSDM)dalam bentuk pelatihan, studi banding maupun magang untuk meningkatkan kemampuan teknis, kemampuan manajerial dan kemampuan kewirausahaan.

Secara umum kegiatan PSDM yang telah dilakukan dinilai berkembang ditinjau dari sisi perkembangan sasaran penerima manfaat, peningkatan ekonomi, peningkatan pengetahuan dan keterbukaan lapangan kerja. Kegiatanpengembangan sumber daya ekonomi (PSDE) telah bermanfaat padapeningkatan perkembangan sasaran penerima manfaat, peningkatan ekonomi, peningkatan pengetahuan dan ketrampilan dan peningkatan keterbukaan lapangan kerja

Berdasarkan analisis tersebut dapat dinyatakan kegiatan PSDA yang telah dilakukan bermanfaat pada peningkatan sasaran penerima manfaat, peningkatan ekonomi, keterbukaan lapangan kerja dan peningkatan kualitas lingkungan yang dapat menunjang pendayagunaan sumberdaya lokal kecuali untuk peningkatan pengetahuan dan kete-rampilan yang dinilai masih kurang.

\section{Perspektif Sosial}

Implementasi aspek perspektif sosial adalah dalam bentuk interaksi, kerjasama, kolaborasi dan deseminasi serta upaya membangun reputasi adalah melalui mekanisme koordinasi, monev serta pertanggungjawaban. Interaksi antara BKAD dan masyarakat dilakukan dilakukan melalui program PSDM, PSDA dan PSDE yang diwujudkan dalam agenda pertemuan yang telah direncanakan sebe-lumnya.

Interaksi dan koordinasi BKAD dengan masyarakat dan antar pengurus dan stakeholder lainnya dinilai baik.Pemerintah daerah di tiga Kabupaten dinilai cukup aktif terlibat dalam mendukung pelaksanaan P2SLBK. Koordinasi antar pengurus dilakukan setiap minggu sekali. Untuk Kabupaten Malang monev dari para pengawas BKAD ke BKAD/UPKu maupun dari pengurus BKAD ke UPKu masing-masing dilakukan 2 kali dalam satu bulan. Mekanisme koordinasi yang dilakukan antar pengurus BKAD dilakukan 2 kali/ bulan, sedangkan untuk koordinasi dengan pengawas sekali setiap bulan.

Partisipasi masyarakat nampak sejak proses perencanaan dan pembentukan BKAD dalam wadah musyarawah desa, tingkat partisipasi yang dinilai belum ada adalah peran serta masyarakat dalam permodalan BKAD. P2SLBK ini juga telah merangsang dan meningkatkan kemauan masyarakat untuk berwirausaha. Hal ini ditunjukkan dengan besarnya minat masyarakat untuk menjalin kerjasama dengan BKAD dalam mengembangkan usahanya maupun merintis usaha baru. Kerjasama ini membawa dampak (i) mempermudah akses masyarakat untuk mendapatkan fasilitas kredit lunak, dan (ii) peningkatan pendapatan bagi nasabah, Selain peningkatan pendapatan, pengelolaan UEP juga telah memberikan pendapatan kepada PAD Desa, dana sosial. 


\section{Perspektif Struktural}

Fokus perhatian perspektif ini adalah bagaimana menciptakan proses, budaya dan iklim kerja yang baik.Hasil analisis terhadap pengelolaan kelembagaan BKAD menunjukkan bahwa BKAD P2SLBK mempunyai prestasi pengelolaan kelembagaan yang baik dengan nilai skor aktivitas lembaga 1 , sarana dan prasarana 0,94 , administrasi 0,9 dan prestasi lembaga 0,94 .

Demikian halnya dengan kelembagaan UPKu juga mempunyai prestasi pengelolaan kelembagaan yang baik dengan nilai skor aktivitas lembaga 0.89 , sarana dan prasarana 0,76 , administrasi 0,85 dan prestasi lembaga 0,83. 6 UPKu P2SLBK mempunyai prestasi pengelolaan kelembagaan yang baik dan 3 UPKu mempunyai prestasi pengelolaan kelem-bagaan cukup

\section{Perspektif Humanitas}

Dalam perspektif ini yang menjadi perhatian adalah bagaimana membina dan mengembangkan knowledge worker dalam intelektual, kepakaran dan komitmen menghasilkan knowledge yang dalam hal ini menyangkut potensi kemampuan, kemampuan implementasi, kemampuan saling mendistri- busikan pengetahuan dan kemauan meningkatkan pengetahuannya

Dalam Pelaksanaannya BKAD dan UPKu dikelola oleh pengurus dengan latar belakang pendidikan BKAD minimal SMA sampai jenjang pendidikan S-1 dan dari berbagai pekerjaan seperti guru, PNS, dan swasta.dapat disimpulkan bahwa dari aspek pendidikan dan pengetahuan cukup baik untuk dapat mengelola BKAD dan UPKu de-ngan baik meskipun ada beberapa permasalahan yaitu: 1) ada beberapa pengurus yang minatnya tidak sesuai dengan tugas yang diemban dan 2) tenaga kerja yang terlibat seringkali keluar akibat mendapatkan pekerjaan yang lebih baik. Namun demikian besarnya keinginan dan adanya kewa-jiban untuk mengembangkan program, seluruh pengelola selalu terlibat dalam kegiatan untuk mening-katkan kemampuan seperti pelatihan, seminar dan pameran baik yang dilakukan oleh pemda provinsi dan kabupaten, perguruan tinggi maupun instansi lainnya.

\section{Pengembangan Model KM Scorecard}

Pengembangan model KM Scorecard sebagaimana ditunjukkan pada Gambar 1.

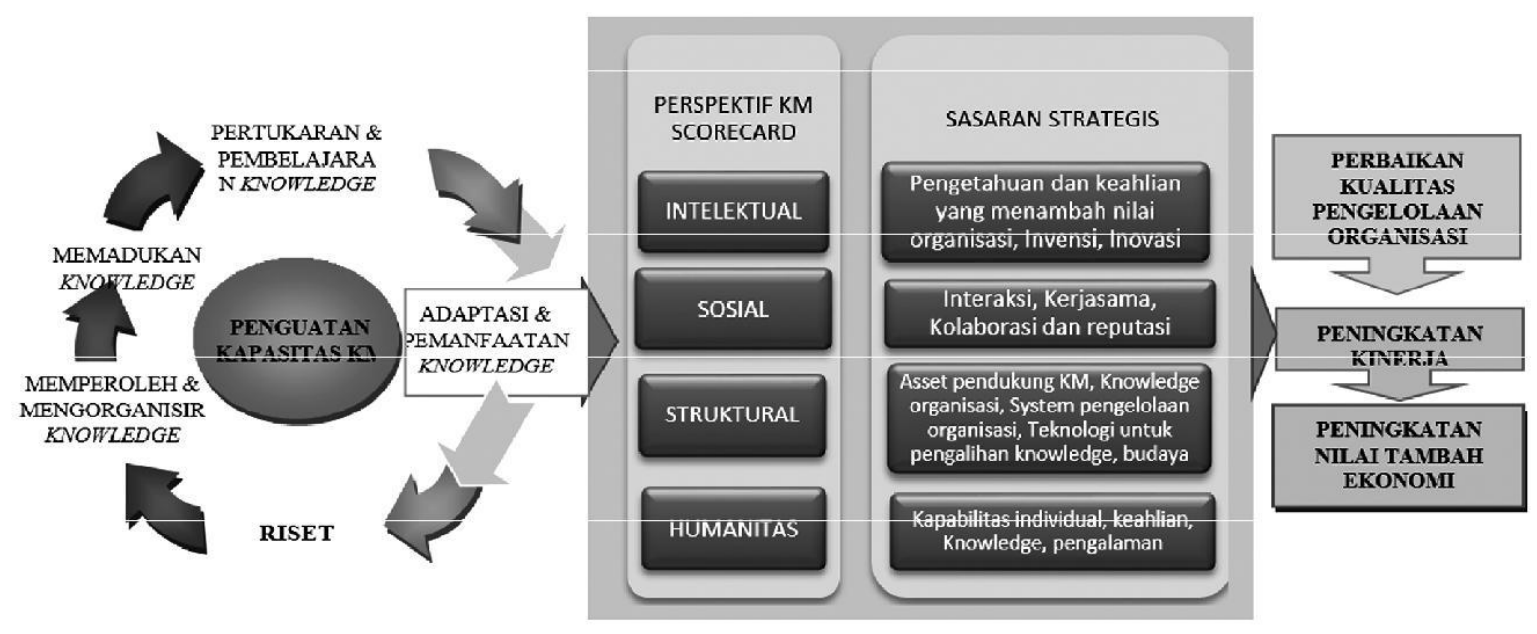

Gambar 1: Pengembangan Model KM Scorecard 


\section{Kinerja BKAD dan UPKu Program Pengembangan Sumberdaya Lokal Berbasis Kawasan (P2SLBK) di Propinsi Jawa Timur}

Hasil temuan penelitian di lapang setelah diujicobakan model selanjutnya dilakukan penilaian kinerja BKAD dan UPKu yang dilihat dari sisi perkembangan aset, perguliran dana, penerima manfaat, penyerapan tenaga kerja, pendapatan, biaya dan SHU masing-masing BKAD dan UPKu. Dilihat dari sisi jumlah aset yang di-pergunakan oleh BKAD dan UPKu untuk kegiatan pengelolaan usaha ekonomi produktif yang pada awal program untuk BKAD senilai Rp 1.335. 254.377,- telah berkembang sebesar $25,8 \%$ menjadi Rp 1.679.180.255,-. Dan untuk UPKu dari senilai Rp 660.579.402,- pada awal program meningkat 29,3\% menjadi Rp 853.930.632,--

Nilai asset tertinggi dicapai oleh BKAD adalah BKAD Kabupaten Ponorogo dengan nilai aset Rp 391.268.083,- dan nilai aset terendah adalah BKAD Kabupaten Pacitan senilai Rp 203.413.850,-. Sedangkan untuk UPKu, terendah adalah UPKu Kabupaten Probolinggo dengan nilai asset sebesar Rp 106.180.200,-. Sedangkan nilai asset tertinggi dicapai oleh UPKu Kabupaten Tulungagung dengan nilai asset sebesar Rp 214.478.640,--

Dilihat dari perkembangan aset, rata-rata perkembangan aset seluruh kabupaten untuk BKAD sebesar 37,2\% dan UPKu sebesar $36,1 \%$. Perkembangan aset terendah untuk BKAD dicapai oleh Kabupaten Probolinggo -0,2\% sedangkan yang tertinggi adalah Kabupaten Ponorogo 136,8\%. Untuk UPKu perkembangan aset terendah Kabupaten Probolinggo sebesar 0\% dan tertinggi kabupaten Tulungagung 124,8\%. Capaian ini di-pengaruhi oleh besarnya asset yang dimiliki oleh BKAD dan UPKu.

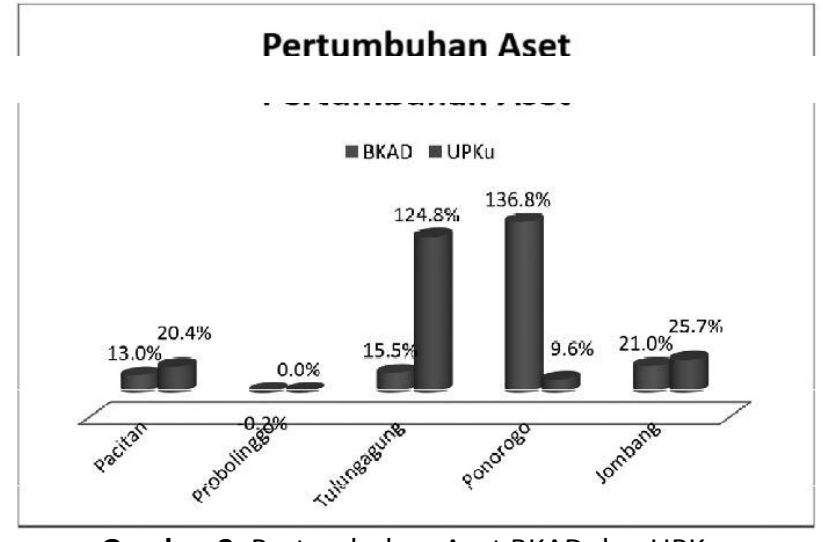

Gambar 2. Pertumbuhan Aset BKAD dan UPKu Masing-masing Kabupaten di Jawa Timur

Disamping itu pencapaian perkembangan asset tersebut menunjukkan bervariasinya perguliran dana, kolektabilitas piutang dari nasabah dan profitabilitas masing-masing BKAD dan UPKu. Ukuran efektivitas kinerja berikutnya adalah peningkatan jumlah penerima manfaat tersebut.

Pencapaian tertinggi untuk indikator ini adalah untuk penerima manfaat BKAD tertinggi adalah Kabupaten Tulungagung sebanyak 98 mitra dan terrendah dicapai Kabupaten Pacitan dan Jom-bang sebanyak 28 mitra. Sedangkan dari kegiatan simpan pinjam UPKu penerima manfaat tertinggi adalah UPKu Kabupaten Jombang sebanyak 381 nasabah dan terendah adalah UPKu Kabupaten Probolinggo sebanyak 106 nasabah.

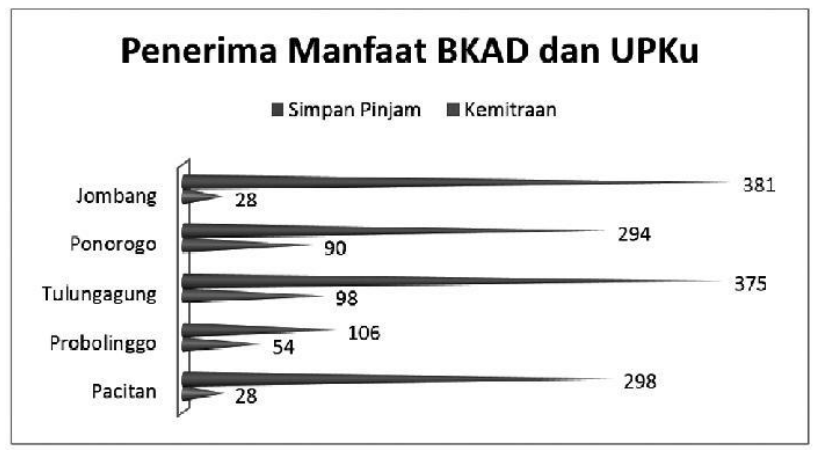

Gambar 3. Penerima Manfaat BKAD dan UPKu Masing-masing kabupaten di Jawa Timur 
Pencapaian indikator ini sangat dipengaruhi oleh persepsi masyarakat terhadap institusi BKAD dan UPKu terutama yang menyangkut kemudahan dari sisi administratif dimana semua unit usaha ekonomi produktif dalam UPKu mensyaratkan adanya jaminan untuk dapat mengakses dana tersebut dan besarnya bunga. Disamping itu kebijakan pengurus terkait dengan nominal dana yang digulirkan dan lama waktu pengembalian pinjaman menyebabkan cukup bervariasinya jumlah mitra, nasabah maupun jumlah dana yang digulirkan. Khususnya di Kabupaten Poorogo adanya prinsip kehati-hatian akibat trauma pembayaran yang macet menyebabkan jumlah penerima manfaat sedikit.

Keterkaitan antara besarnya penerima manfaat berhubungan erat dengan besar dana yang bergulir ke masyarakat. Dari hasil analisis sebagaimana ditunjukkan gambar 4. menunjukkan bahwa jumlah dana yang bergulir untuk BKAD terbesar di capai oleh BKAD Kabupaten Tulungagung sebesar Rp 397.755.000,- dan terrendah dicapai oleh BKAD Kabupaten Probolinggo sebesar Rp 141.333.000,-. Sedangkan untuk dana bergulir simpan pinjam tertinggi dicapai oleh UPKu Kabupaten Tulungagung sebanyak Rp 383.921.500,dan terendah dicapai oleh Kabupaten Probolinggo sebanyak Rp 105.120.200,-.

\section{Dana Bergulir BKAD dan UPKu}

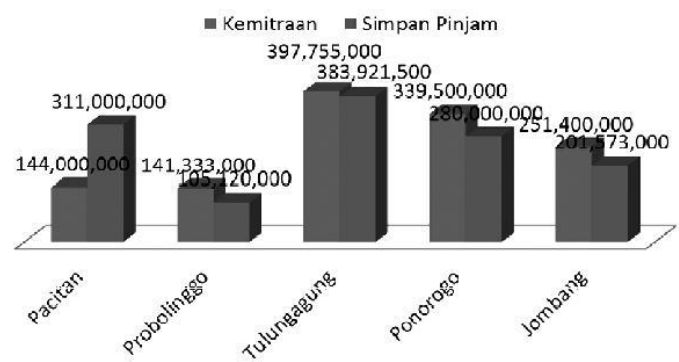

Gambar 4. Dana Bergulir BKAD dan UPKu MasingMasing Kabupaten di Jawa Timur
Penyaluran dana kepada masyarakat akan berkaitan dengan selektivitas calon penerima dana tersebut. Dalam hal ini terdapat proses penilaian kelayakan personal dan keuangan yang mesti harus dilalui oleh calon penerima manfaat. Pro-sedur yang demikian merupakan prosedur standar yang harus dilaksanakan oleh lembaga keuangan. Pada akhirnya semua mekanisme tersebut akan ber-guna dalam menjaga performance dari Kualitas Aktiva Produktif yang dikelola. Penyaluran dana yang diikuti dengan seletivitas yang ketat terha-dap kelayakan calon penerima dana akan berujung pada meningkatnya performance Kualitas Aktiva Produktif.

Sejalan dengan kondisi di atas adalah pada sisi kemampuan dalam meraih pendapatan dan mengendalikan biaya operasional. Sebagaimana diketahui pendapatan operasional UPK akan ter-diri dari pendapatan yang berasal dari unit ekonomi produktif yang dikelola sementara biaya operasionalnya mencakup biaya pengurus, biaya ATK, serta transportasi. Berdasarkan besarnya pendapatan dan biaya operasional tersebut diperoleh nilai efisiensi BKAD. BKAD yang paling efisien dicapai oleh Kabupaten Tulungagung sebesar 1,3\% sedangkan yang tidak efisien dicapai oleh Kabupaten Probolinggo sebesar 66,5\%.

Pada akhirnya kinerja keuangan suatu organisasi akan berujung pada kemampuan intitusi tersebut memperoleh laba (Sisa Hasil Usaha) melalui asset yang dimilikinya. Distribusi nilai profitabilitas dapat dilihat pada gambar 5. Profitabilitas terendah yang dicapai adalah 3\% yaitu oleh Kabupaten Probolinggo, sementara yang tertinggi mencapai 41,7\% yaitu Kabupaten Pacitan.

Sisa hasil usaha tersebut merupakan resultan dari volume usaha yang berhasil dikelola dengan biaya yang dikeluarkan. Jika volume usaha yang dikelola mengalami peningkatan yang diikuti dengan efisiensi biaya maka dapat dipastikan pro-fitabilitas yang diraih akan tinggi. 


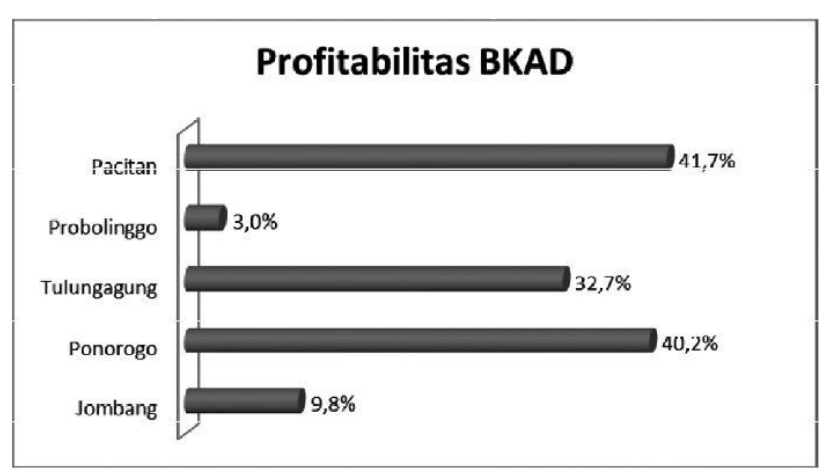

Gambar 5. Profitabilitas BKAD masingmasing Kabupaten di Jawa Timur

Sedangkan proporsi antara pendapatan dan biaya UPK yang membentuk sisa hasil usaha ditun-jukkan dalam tabel berikut ini:

Berdasarkan tabel tersebut, temuan di lapangan menunjukkan bahwa kegiatan BKAD dan UPKu di 5 Kabupaten mengalami keuntungan yang ditunjukkan dengan adanya sisa hasil usaha secara keseluruhan BKAD dan UPKu sebesar Rp 188.200.325,-. Adapun total pendapatan yang dihasilkan sebesar Rp. 255.394.592,-. dan untuk biaya yang telah dikeluarkan sebesar Rp.67.194.267,-.

Dilihat dari sisi pendapatan yang memiliki pendapatan tertinggi adalah BKAD dan UPKu Kabupaten Ponorogo dengan jumlah pendapatan sebesar Rp. 83.525.730,-, hal ini mengisyaratkan kemampuan BKAD dan UPKu dalam mengoptimalkan aktiva produktifnya sangat baik dalam rangka menghasilkan pendapatan. Hal ini juga menunjukkan bahwa BKAD dab UPKu juga selektif dalam dalam rangka penyaluran kreditnya. Sedangkan
BKAD dan UPKu yang memiliki pendapatan teren-dah adalah BKAD dan UPKu Kabupaten Probo-linggo dengan jumlah pendapatan sebesar Rp. 9.355.703,--

Biaya operasional bagi BKAD dan UPKu adalah cerminan dalam rangka membiayai operasional guna mendapatkan keuntungan yang diinginkan. Biaya operasional tertinggi adalah BKAD dan UPKu Kabupaten Ponorogo dengan jumlah biaya operasional yang dikeluarkan sebesar Rp. 34.520.022,-. Sedangkan BKAD dan UPKu yang memiliki biaya terendah adalah BKAD dan UPKu Kabupaten Tulungagung dengan jumlah biaya yang dikeluarkan sebesar Rp. 947.588,-. Sisa Hasil Usaha merupakan keuntungan usaha yang dihasilkan oleh BKAD dan UPKu dalam satu tahun periode kegiatan. BKAD dan UPKu yang memiliki sisa hasil usaha tertinggi adalah BKAD dan UPKu Kabu-paten Tulungagung dengan jumlah sebesar Rp. 70.044.645,-. Kondisi tersebut menunjukkan BKAD dan UPKu Kabupaten Tulungagung memiliki kemampuan melakukan pengelolaan usaha dengan baik sedangkan BKAD dan UPKu yang memiliki sisa hasil usaha terendah adalah BKAD dan UPKu Kabupaten Probolinggo sebesar Rp. 3.133.051,--

Keberlanjutan dan Pelestarian Program merupakan hal yang penting dilakukan agar P2SLBK dapat memberikan kontribusi bagi peningkatan kesejahteraan masyarakat di masa-masa mendatang. Mengingat keberlanjutan dan pelestarian program menjadi factor yang krusial, maka perlu perhatian dan partisipasi dari berbagai pihak yang

Tabel 3. Penilaian Kinerja pada 5 kabupatenDi Propinsi Jawa Timur

\begin{tabular}{lrrr}
\hline \multicolumn{1}{c}{ Kabupaten } & Pendapatan & \multicolumn{1}{c}{ Biaya } & \multicolumn{1}{c}{ SHU } \\
\hline Jombang & $35,691,926$ & $17,455,095$ & $18,236,831$ \\
Ponorogo & $83,525,730$ & $34,520,022$ & $49,005,708$ \\
Tulungagung & $70,992,233$ & 947,588 & $70,044,645$ \\
Probolinggo & $9,355,703$ & $6,222,652$ & $3,133,051$ \\
Pacitan & $55,829,000$ & $8,048,910$ & $47,780,090$ \\
\hline
\end{tabular}




\section{Jurnal Keuangan dan Perbankan | PERBANKAN}

Vol. 20, No.2, Mei 2016: 322- 333

berkepentingan agar hasil-hasil kegiatan P2SLBK dapat dilestarikan. Semua yang dihasilkan melalui program P2SLBK dapat dijadikan modal oleh daerah untuk pengembangan wilayah di bidang ekonomi dan menjadi upaya penanggulangan kemiskinan. Modal yang dimaksud adalah sarana/ prasarana, sistem, kelembagaan dan kegiatan dana bergulir. Berdasarkan hasil interview secara informal dari beberapa penerima manfaat mereka menyatakan bahwa Program Pengembangan Sumberdaya Lokal Berbasis Kawasan dapat memberikan stimulasi pada masyarakat untuk melaksanakan kegiatan ekonomi produktif dan mengembangkan investasi di desa. Hasil-hasil pelaksanaan program khususnya bidang PSDA telah diselesaikan dan telah dirasakan manfaatnya oleh masyarakat sehingga diharapkan setelah tahap pemandirian pemerintah tingkat desa dan masyarakat sanggup melestarikan hasil-hasil P2SLBK bidang PSDA.

Berdasarkan hasil pengamatan di lapangan untuk kegiatan PSDM, dirasakan bermanfaat bagi pengetahuan dan kegiatan usaha. Disamping itu dalam pelatihan tersebut teradapat kesesuaian materi pelatihan dengan karaktristik wilayah, kebutuhan pelaku usaha. Untuk usaha simpan pinjam harapan masyarakat kegiatan terus untuk dilanjutkan dengan berbagai alasan antara lain bunga pinjaman yang ringan, dapat menambah permodalan usaha serta dapat digunakan untuk kebutuhan keluarga yang mendesak. Fakta ini ditunjukkan oleh banyaknya para calon nasabah yang harus antri untuk mendapatkan pinjaman. Komitmen dan kemampuan masyarakat untuk pelestarian program cukup besar. Hal ini dapat dilihat dari komitmen masyarakat untuk memberlakukan sanksi bagi mitra atau nasabah yang tidak konsisten dalam membayar angsuran. Selain itu, tokoh masyarakat di masing-masing lokasi program juga aktif melakukan pengawasan terhadap pelaksanaan kegiatan BKAD dan UPKu. Sedangkan BKAD dan UPKu sebagai pengelola program sebagian besar juga menunjukkan komitmen yang tinggi untuk melestarikan program dan salah satu usahanya rutin mendatangi nasabah yang kesulitan dalam mengangsur serta melakukan dis-kusi untuk mencari solusi dalam menyelesaikan permasalahan yang ada.

\section{KESIMPULAN}

Berdasarkan hasil penelitian maka dapat disimpulkan:

1. Penyelenggaraan program telah sesuai dengan proses dan mekanisme yang telah ditentukan dalam SOP dan SPP P2SLBK

2. Secara umum pelaksanaan program di bidang Pengembangan Sumberdaya Manusia (PSDM), Pengembangan Sumberdaya Alam(PSDA) dan Pengembangan Sumber Daya Ekonomi (PSDE) telah menghasilkan peningkatan ekonomi, peningkatan pengetahuan dan ketrampilan, membuka lapangan kerja dan menumbuhkan kesempatan berwirausaha

3. Ditinjau dari pengembangan usaha sektor riil, sejumlah Lembaga Keuangan Mikro "BKAD" P2SLBK telah berhasil mengembangkan usaha sektor riil berbasis sumberdaya kawasan yang sesuai dengan potensi wilayah masing-masing

4. Pengelolaan KM dalam perspektif KM Scorecard secara umum berjalan dengan baik dan telah menghasilkan peningkatan ekonomi, pening-katan pengetahuan dan ketrampilan, mem-buka lapangan kerja dan menumbuhkan ke-sempatan berwirausaha serta berhasil mengem-bangkan usaha sektor riil berbasis sumberdaya kawasan yang sesuai dengan potensi wilayah-nya. Oleh karenanya perlu terus menerus dila-kukan upaya untuk mengembangkan kemam-puan Knowledge Management (KM) dengan lebih baik agar tujuan untuk meningkatkan profe-sionalitas pengelolaan dan peningkatan kinerja Lembaga Keuangan Mikro "BKAD” dapat ter-capai. 


\section{Implementasi Model Penilaian Kinerja Berbasis Knowledge Management Score Card...}

Yuntawati Fristin, Fajar Supanto, \& Umu Khouroh

\section{REFERENSI}

Bontis, Nick. 2005. National Intellectual Capital Index: The Benchmarking of Arab Countries.

Bounfour, Ahmed and Leif Edvinsson. 2005. Intellectual Capital for Communities Nations, Regions, Cities. Oxford: Elsevier.

Fairchid, Alea M, 2002, Knowledge Management Metrics via a Balance Scorecard Methodology, Annual Hawaii International Conference on Systems Sciences.

Kaplan, Robert S. and Norton, David, 1996, The Balance Scorecard-Translating Strategi into Action, Harvard Business School Press
Kaplan, Robert S. and Norton, David, 2004 Strategy Maps: Converting Intangible Assets into TangibleOutcomes. Harvard Business School Press

Lewin, Peter and Steven E. Phelan. 1999. Rent and Resources: A Market Process Perspective. An unpublished draft of report. Dallas, Texas: University of Texas.

Nonaka, I. 1995. The Knowledge Creating Company. New York: Oxford University Press. 
